\title{
Does body posture during tree felling influence the physiological load of a chainsaw operator?
}

\author{
Witold Grzywiński ${ }^{1}$, Tomasz Jelonek ${ }^{1}$, Arkadiusz Tomczak' ${ }^{1}$, Marcin Jakubowski', \\ Mariusz Bembenek ${ }^{1}$ \\ ${ }^{1}$ Poznań University of Life Sciences, Faculty of Forestry, Poland
}

Grzywiński W, Jelonek T, Tomczak A, Jakubowski M, Bembenek M. Does body posture during tree felling influence the physiological load of a chainsaw operator? Ann Agric Environ Med. 2017; 24(3): 401-405. doi: 10.5604/12321966.1235177

\begin{abstract}
Introduction and Objectives. Holding determined body postures during work is connected with muscles activity. The more forced the posture, the larger the number of muscles taking an active part in holding and stabilizing the work posture. During logging, the greatest share of awkward (forced) working postures occurs in tree felling by chainsaw.

Materials and Method. A group of 10 experienced fellers aged 47.5 \pm 7.3 (37 - 59-years-old) was studied. Heart rate (HR) was measured during simulation of felling activity in 4 working postures: back bent forward with straight legs (stoop), back bent forward with bent legs (flexed-stoop), squat and kneeling on one knee (half-kneel).

Results. The lowest value of HR was noticed for squatting - $114.1 \mathrm{bpm}$, then for kneeling on one knee - 116.3 bpm. HR during felling in a standing posture with straight legs amounted to $121.5 \mathrm{bpm}$ and for standing with bent legs $125.3 \mathrm{bpm}$. For all studied postures the differences in average HR values were statistically significant at $p<0.01$.

Conclusions. A working posture during tree felling by chainsaw has influence on the level of physiological workload of an operator. Standing bent forward body postures cause higher heart response than squatting and half-kneeling.
\end{abstract}

Key words

working posture, heart rate, forestry, feller, felling

\section{INTRODUCTION}

Forestry is an important sector of the economy in many countries of the world. Despite advancing mechanization of work, logging in many countries is still at the motor-manual level. Motor-manual timber harvesting is considered to be one of the hardest and most dangerous types of work $[1,2$, $3,4]$. Average values of heart rate (HR) during chainsaw operating oscillate between 110-138 bpm [5, 6, 7, 8, 9]. Logging using a chainsaw also creates a large load on the musculoskeletal system as a result of adopting awkward (forced) postures during operations. The largest load occurs when felling trees with a chainsaw $[8,10,11,12]$. Studies show that the incidence of musculoskeletal disorders of chainsaw operators is very high $[13,14,15,16,17]$.

The method to reduce the burden of work in logging is the introduction of multi-operational machines. In a few countries (Sweden, Finland), almost all timber is harvested by this method. A significant proportion of fully-machine harvesting is also present in the countries of Western Europe [18]. In most countries of the world, traditional timber harvesting using a chainsaw still dominates [19], for example, in Poland (Central Europe) in 2014 almost 40 million $\mathrm{m}^{3}$ of timber were harvested, of which more than $80 \%$ using chainsaws [20]. Such a large amount of harvested raw timber requires an adequate number of employees, and in Poland it is estimated that more than 10,000 people work in the logging profession [11].

Maintaining a specific body posture during operation requires the involvement of the relevant muscle groups. The locomotive principle is based on the dynamic equilibrium of

Address for correspondence: Witold Grzywiński, University of Life Sciences, Faculty of Forestry, Wojska Polskiego 71A, 60-625 Poznań, Poland

E-mail: witold.grzywinski@up.poznan.pl

Received: 5 July 2016; accepted: 9 February 2017; first published: May 2017 the posture which, excluding the free lying posture, always requires muscle tension [21]. The greater the degree of forcing the posture, the greater the number of muscle taking an active part in maintaining and stabilizing the of body posture. Working muscles need an appropriate amount of oxygen and energy substrates delivered by the circulatory system. Thus, postures that require greater involvement of muscles are characterized by a greater physiological strain [22].

Chainsaw felling of trees can be performed in different postures [8, 11]. Unfortunately, available data on the physiological load on a logger while felling trees do not take into account the body posture in which the operation was performed. There are also only a few studies concerning the physiological load while performing other work in different body postures. Vos [23], in laboratory conditions, studied workload by measuring the heart rate while working in 5 postures. Heart rate was defined as an increase of $\mathrm{HR}$ in relation to the resting heart rate $\left(\mathrm{HR}_{\text {rest }}\right)$ in a sitting posture. Individual HR values observed in the subjects were higher compared with $\mathrm{HR}_{\text {rest }}$ by about 14-25 strokes in a squatting and 19-38 heart beats in a squatting without support of hands, and standing with strongly inclined body.

\section{OBJECTIVE}

The aim of the study was to determine the extent to which different working postures while felling trees affect the amount of physiological strain of the chainsaw operator, and attempt to indicate the postures that will help reduce the arduousness of work during the motor-manual harvesting of timber. 


\section{MATERIALS AND METHOD}

\section{Study design}

The possibility of measuring the physiological load during felling of trees with a chainsaw in different postures during the process of timber harvesting is limited due to difficulties in maintaining the established posture of the body. Therefore, simulation studies were planned, in which a group of 10 experienced fellers (all men) participated. The characteristics of the study group are presented in Table 1.

The study was conducted at 4 sites of pine trees. During the harvesting of the trees, a part of them were cut higher
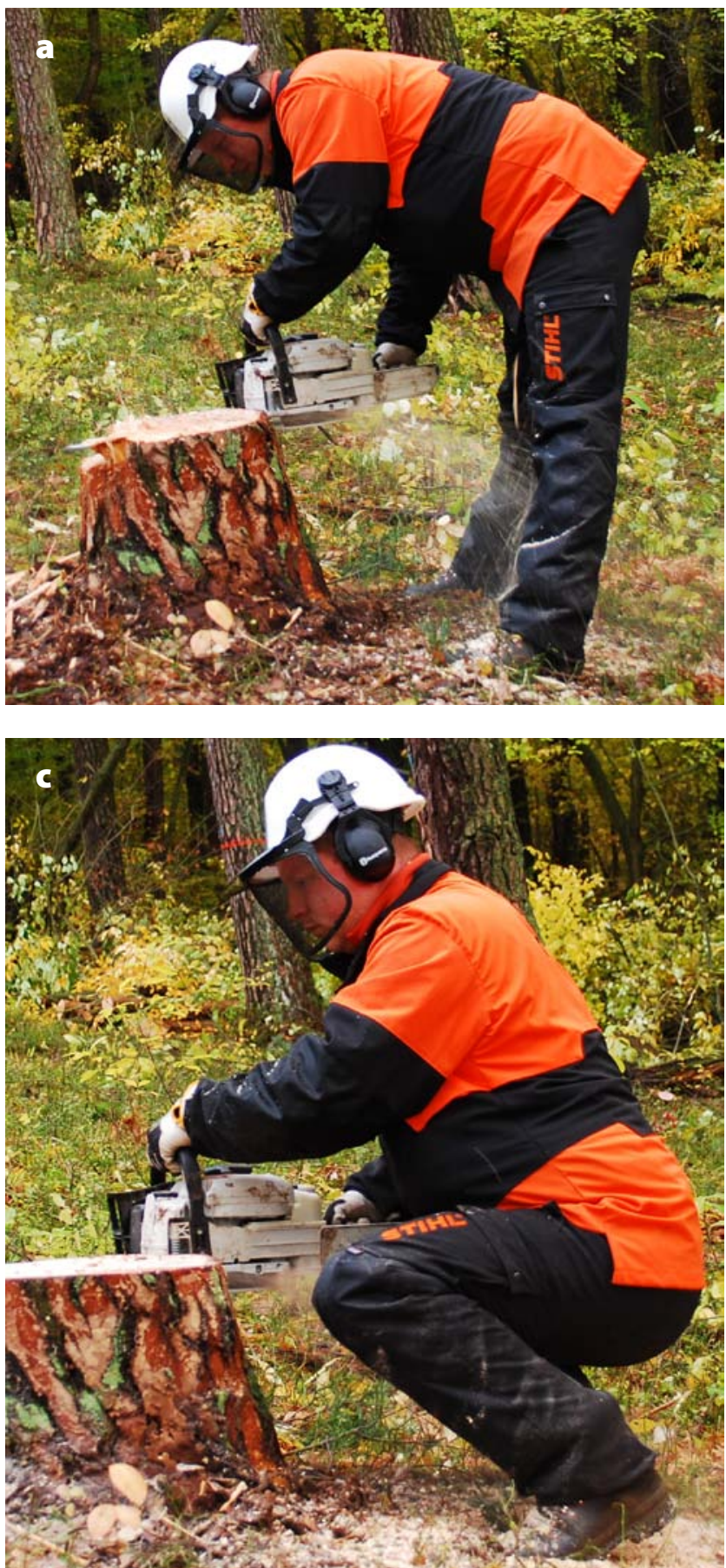

(approx. $30 \mathrm{~cm}$ above ground). Stumps were located close together to minimize the possible impact of the move. The fellers cut thin slices from the stumps. The diameter of the stumps was chosen so as not to exceed the effective length of the chainsaw guide bar. Each of the fellers cut about 30 slices. Cutting was carried out with a Stihl MS 361 chainsaw with a capacity of $3.4 \mathrm{~kW}$ and a weight of $7.5 \mathrm{~kg}$. The average air temperature during the study was $7.1 \pm 4.8^{\circ} \mathrm{C}$, humidity $72 \pm 6.7 \%$.

The physiological stress of fellers was measured on the basis of the measurement of a constant heart rate. This method is often used for assessing the physiological workload, also
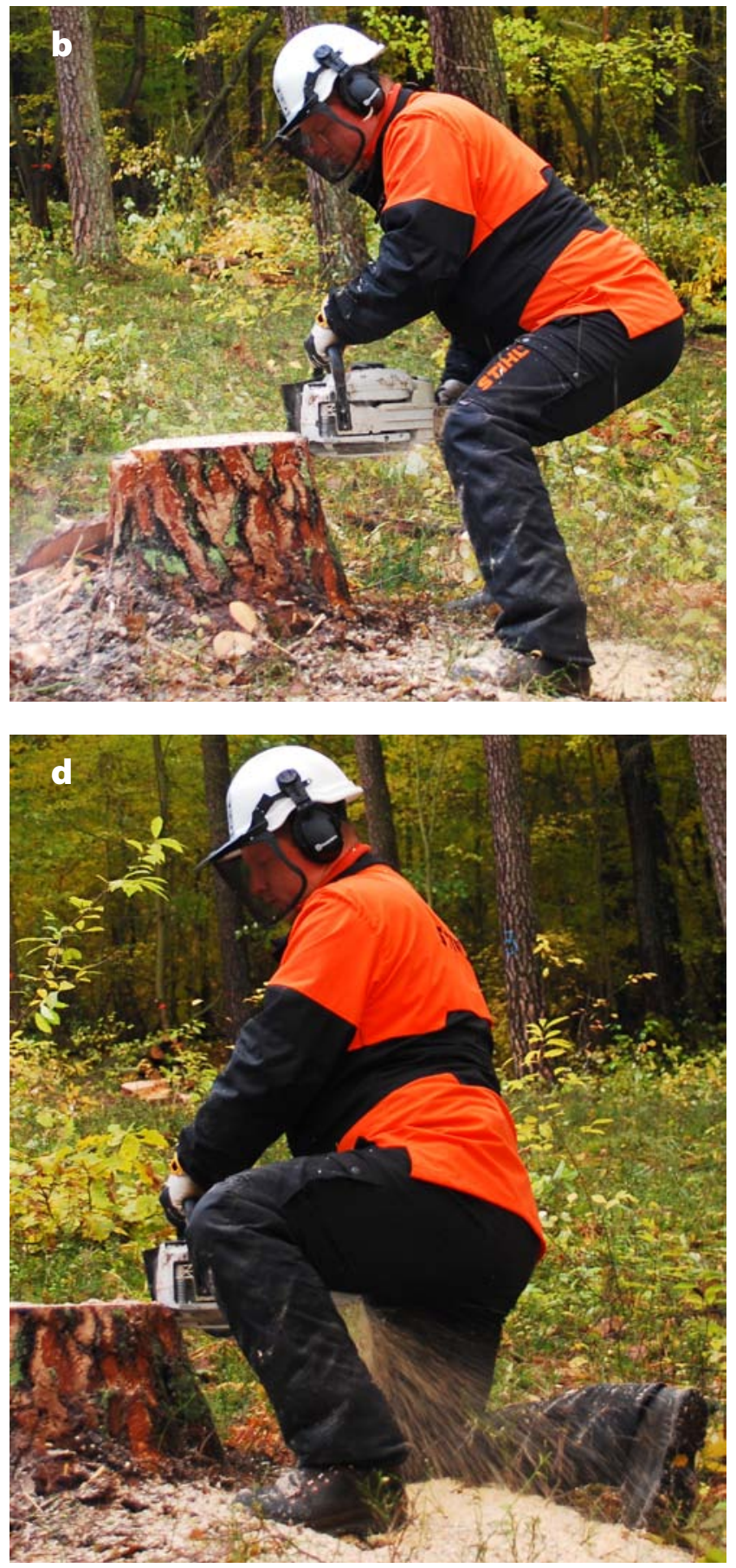

Figure 1. Body postures selected for the measurement of physiological load during tree cutting: a - back bent forward with straight legs (stoop), b - back bent forward with bent legs (flexed-stoop), c - squat, d - kneel on one knee (half-kneel). Photo by W. Grzywiński 
in forestry $[24,25]$. The 4 most common working postures adopted by the fellers were selected $[4,11]$ : back bent forward with straight legs (stoop), back bent forward with bent legs (flexed-stoop), squat and kneeling on one knee (half-kneel) (Fig. 1). The angle of bending the legs at the knee joint in position with legs bent fluctuated between $45-60^{\circ}$, while in squatting position this was greater than $90^{\circ}$. Measuring $\mathrm{HR}$ in a posture with a bent and twisted back was abandoned due to the difficulty of standardizing this posture.

Heart rate was measured using a heart rate monitor Polar RS800 (Polar Electro, Finland). All heart beats were recorded (beat-to-beat). Data analysis was performed by a dedicated software Polar ProTrainer 5.

Statistical analysis. Statistical analysis was performed using STATISTICA 11.0 (StatSoft, Poland). Preliminary analysis showed non-compliance of heart rate distribution during felling of trees in different postures with a normal distribution. Non-parametric Kruskal-Wallis test was applied to compare differences between HR among particular working postures. In this case, significant difference at $\mathrm{p}<0.05$ was found, post hoc cross-comparisons between particular postures were performed using the Dunn test.

Table 1. Basic anthropometric characteristics of fellers $(n=10)$

\begin{tabular}{cccccc}
\hline No. of feller & $\begin{array}{c}\text { Age } \\
\text { (years) }\end{array}$ & $\begin{array}{c}\text { Body mass } \\
(\mathrm{kg})\end{array}$ & $\begin{array}{c}\text { Height } \\
(\mathrm{cm})\end{array}$ & $\begin{array}{c}\text { BMI } \\
\left(\mathrm{kg} \cdot \mathrm{m}^{-1}\right)\end{array}$ & $\begin{array}{c}\text { Work experience } \\
(\text { years })\end{array}$ \\
\hline 1 & 43 & 80 & 178 & 25.2 & 15 \\
\hline 2 & 38 & 89 & 173 & 29.7 & 20 \\
\hline 3 & 39 & 85 & 176 & 27.4 & 19 \\
\hline 4 & 37 & 85 & 187 & 24.3 & 13 \\
\hline 5 & 51 & 75 & 181 & 22.9 & 10 \\
\hline 6 & 56 & 100 & 170 & 34.6 & 13 \\
\hline 7 & 53 & 84 & 172 & 28.4 & 11 \\
\hline 8 & 59 & 67 & 166 & 24.3 & 22 \\
\hline 9 & 51 & 70 & 168 & 24.8 & 21 \\
\hline 10 & 48 & 98 & 172 & 32.4 & 21 \\
\hline Mean & 47.5 & 83.3 & 174.3 & 27.4 & 16.5 \\
\hline Std. deviation & 7.31 & 10.87 & 6.87 & 3.57 & 4.55 \\
\hline Range & $37-59$ & $67-100$ & $166-187$ & $22.9-34.6$ & $10-22$ \\
\hline
\end{tabular}

\section{RESULTS}

The average value of the heart rate during felling in the tested postures ranged from 114.1-125.3 bpm (Tab. 2). The lowest heart rate was found for squatting, then the half-kneeling $116.3 \mathrm{bpm}$. Standing with legs straight, and then bent (stoop and flexed-stoop) were characterized by higher levels of load. During felling in a posture with legs straight, the average number of heart beats per minute amounted to 121.5, while when cutting with legs bent -125.3 . The observed differences in mean HR between all analysed body postures during chainsaw felling were statistically significant at the level of $\mathrm{p}<0.01$. Particular fellers were characterized by a wide range of heart rate values in all studied postures (Tab. 2).

For flexed-stoop, squat and half-kneel, a similar pattern of HR values distribution was observed in all 3 (first, second and third quartiles). In these three postures, a significant increase of HR was noticed in the third quartile. In case of stoop posture, HR increased rapidly in low values; however, for higher values, the trend was similar to other postures (Fig. 2).

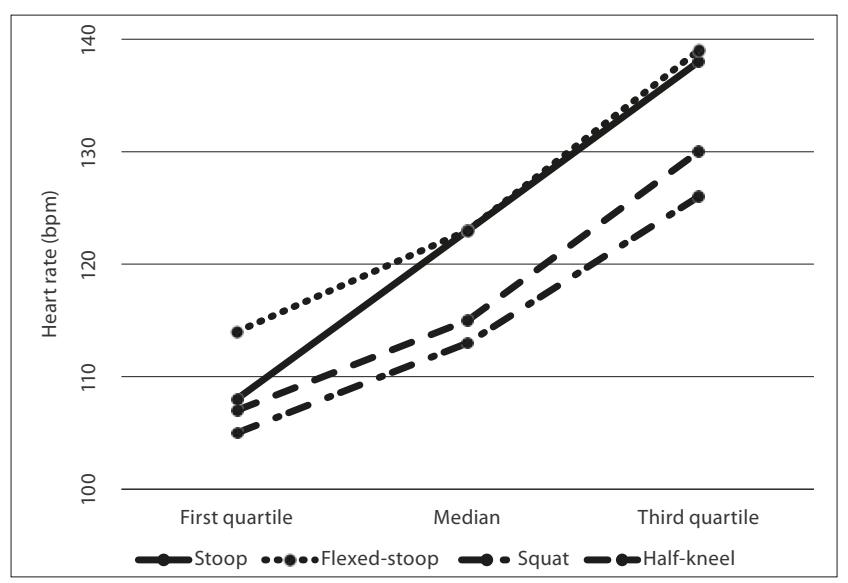

Figure 2. The distribution of HR values in the studied postures

\section{DISCUSSION}

Body posture during felling operation may significantly affect the amount of physiological workload. This is illustrated by the results of heart rate during the chainsaw felling of trees

Table 2. The characteristics of HR values for particular postures in all participants $(n=10)$

\begin{tabular}{|c|c|c|c|c|c|c|c|c|c|c|c|c|c|c|c|c|}
\hline \multirow{2}{*}{$\begin{array}{l}\text { No. of } \\
\text { feller }\end{array}$} & \multicolumn{4}{|c|}{ Stoop } & \multicolumn{4}{|c|}{ Flexed-stoop } & \multicolumn{4}{|c|}{ Squat } & \multicolumn{4}{|c|}{ Half-kneel } \\
\hline & $\mathrm{N}$ & Mean & SD & Range & $\mathrm{N}$ & Mean & SD & Range & $\mathrm{N}$ & Mean & SD & Range & $\mathrm{N}$ & Mean & SD & Range \\
\hline 1 & 657 & 133.3 & 9.38 & $102-146$ & 657 & 133.0 & 5.98 & $109-145$ & 657 & 123.0 & 8.21 & $90-138$ & 590 & 118.5 & 6.59 & $105-135$ \\
\hline 2 & 203 & 137.5 & 4.92 & $123-147$ & 657 & 116.8 & 6.98 & $99-130$ & 570 & 110.3 & 6.11 & $83-129$ & 556 & 111.2 & 5.57 & $91-124$ \\
\hline 3 & 609 & 99.4 & 6.65 & $70-115$ & 544 & 104.0 & 7.50 & 70-119 & 563 & 94.7 & 7.33 & $78-121$ & 500 & 95.0 & 5.89 & 78-112 \\
\hline 4 & 628 & 117.8 & 6.12 & $101-130$ & 657 & 116.8 & 6.98 & $99-130$ & 570 & 110.3 & 6.11 & $83-129$ & 556 & 111.2 & 5.57 & $91-124$ \\
\hline 5 & 625 & 115.1 & 4.48 & $98-125$ & 550 & 116.0 & 4.60 & $101-128$ & 611 & 107.4 & 7.11 & $79-126$ & 532 & 108.4 & 5.75 & $93-126$ \\
\hline 6 & 771 & 99.3 & 6.84 & $77-126$ & 689 & 116.4 & 9.38 & $90-138$ & 565 & 101.3 & 8.04 & $72-129$ & 622 & 107.4 & 6.07 & $82-122$ \\
\hline 7 & 810 & 139.5 & 8.57 & $96-153$ & 762 & 139.4 & 10.14 & $101-161$ & 756 & 133.7 & 9.91 & 90-156 & 490 & 135.5 & 10.44 & $106-156$ \\
\hline 8 & 381 & 136.5 & 10.25 & $104-156$ & 381 & 144.3 & 10.65 & $102-162$ & 381 & 116.5 & 6.69 & $97-150$ & 381 & 131.3 & 6.06 & $105-146$ \\
\hline 9 & 144 & 137.7 & 3.04 & $129-143$ & 164 & 141.3 & 3.98 & $133-148$ & 176 & 129.6 & 5.42 & $115-139$ & 210 & 138.1 & 5.10 & $127-150$ \\
\hline Total & 5119 & 121.5 & 17.42 & $70-156$ & 5389 & 125.3 & 15.85 & $70-162$ & 5105 & 114.1 & 14.69 & $72-160$ & 4786 & 116.3 & 14.46 & $78-156$ \\
\hline
\end{tabular}


in different postures presented in this study. The greatest physiological load measured with cardiovascular response was associated with the flexed-stoop posture $(125.3 \mathrm{bpm})$, followed by stoop posture (121.5 bpm). Heart rate when halfkneeling and squatting was lower, and similar, amounting to 114.1 and $116.3 \mathrm{bpm}$, respectively. The obtained values of heart rate classified all postures in the category of 'hard work' (110-130 bpm) [2].

The values of the pulse obtained during the chainsaw felling of trees in different postures correspond with the results of other researchers, who evaluated the load of a logger divided into technological operations or as a whole, without considering the posture of the body. Research among Finnish fellers at work in the winter showed the load at $126 \pm 6 \mathrm{bpm}$ per felling, while the average for all the work performed at their own pace during a single day was $123 \pm 6$ bpm [5]. Average heart rate of the loggers during felling of trees on the plantation amounted to $123.3 \mathrm{bpm}$ [8]. During felling and delimbing of spruce, HR ranged to 110-132 $\mathrm{bpm}$, on average, reaching a value of $122.8 \mathrm{bpm}$ [9]. Chilean researchers observed the average heart rate of a feller during timber harvesting to be $114.2 \mathrm{bpm}$ [7].

Felling is an operation that can be performed in a different spatial orientation of the body segments. The most common is performed in a standing posture, which provide the greatest working range of the upper limbs and the greatest efficiency. Earlier studies have shown that standing with the legs straight accounted for $47 \%$, and with legs bent $33.8 \%$ of all postures of the lower limbs during felling [11].

Body posture during operation is an important biomechanical factor affecting the locomotor system. Awkward postures that are forced are one of the main causes of the development of musculoskeletal disorders [26,27]. The variety of postures during felling with a chainsaw makes it possible to intervene ergonomically, and to promote postures less burdensome, e.g. during training. Similar activities have been successfully carried out in other industries $[28,29$, 30, 31].

From the studied postures, the smallest degree of force is characterized by standing bent with legs straight (stoop) which, as some researchers have shown, is also frequently used by the loggers $[8,11]$. The lowest physiological cost was characterized by squatting and half-kneeling. These postures also allow for smaller tilt of the back and less stress on the lumbar spine during operation. On the other hand, they also inflict a great strain on the joints of the knees and ankles. Kneeling comes into direct contact with the ground, which may accelerate the development of inflammation in the knee. Despite the physiological load when working in these postures, they are not recommended for long-term use.

Chainsaw felling of a single tree usually lasts no longer than a few minutes, and is performed alternating with activities requiring taking less forced postures (delimbing, cross-cutting) and passes. It is therefore possible to use other postures regularly, especially squatting, for short periods of time in order to relieve strain on the lumbar spine.

\section{CONCLUSIONS}

1. Body posture during the felling of trees has an impact on the level of physiological load of the chainsaw operator.
2. The highest cardiovascular response takes place during the felling in the posture with bent back and bent legs (flexed-stoop). Bent posture with straight legs requires less involvement.

3. The lowest HR occurs when working in the squatting and half-kneeling postures.

4. Adopting work postures requiring lesser values of heart rates can help to reduce the physiological strain of loggers during chainsaw felling.

\section{Acknowledgements}

The study was performed as a part of research project N N404 294734: 'The impact of working posture during the felling of trees on the degree of arduousness of logger's work' - funded by the Ministry of Science and Higher Education in Warsaw, 2008-2010.

\section{REFERENCES}

1. ILO. Safety and health in forestry work. ILO, Geneva, 1998.

2. Åstrand P-O, Rodahl K, Dahl HA, Strømme SB. Textbook of work physiology: Physiological bases of exercise. 4th ed. Human Kinetics, Champaign (IL), 2003.

3. Leszczyński K. The concentration of carbon monoxide in the breathing areas of workers during logging operations at the motor-manual level. Int J Occup Med Environ Health. 2014; 27: 821-829.

4. Grzywiński W. Influence of working posture during the felling on energy expenditure of a chainsaw operator. Sylwan. 2015, 159: 824-830 (in Polish with English summary).

5. Kukkonen-Harjula K, Rauramaa R. Oxygen consumption of lumberjacks in logging with a power-saw. Ergonomics. 1984; 27: 59-65.

6. Hagen KB, Vik T, Myhr NE, Opsahl PA, Harms-Ringdahl K. Physical workload, perceived exertion, and output of cut wood as related to age in motor-manual cutting. Ergonomics. 1993; 36: 479-488.

7. Apud E, Valdes S. Ergonomics in forestry. The Chilean case. Geneva: International Labour Organization, 1995.

8. Christie CJ-A. A field investigation of physical workloads imposed on harvesters in South African forestry. Ph.D. Dissertation. Rhodes University, Grahamstown, 2006.

9. Çalişkan E, Çağlar S. An assessment of physiological workload of forest workers in felling operations. Afr J Biotechnol. 2010; 9: 5651-5658.

10. Harstela P. Work postures and strain of workers in nordic forest work: A selective review. Int J Ind Ergon. 1990; 5: 219-226.

11. Grzywiński W. The effect of selected factors on the type of working postures of chainsaw operator during felling. Wyd. UP w Poznaniu, Poznań, 2011 (in Polish with English summary).

12. Sawastian K, Grzywiński W, Turowski R. Analysis of postural strain of loggers during timber harvesting in a spruce stand. For Lett. 2015; 108: $1-6$.

13. ILO. Occupational safety and health in forestry. Forestry and Wood Industries Committee. 2nd Session. Report III. ILO, Geneva, 1991.

14. Hagen KB, Magnus P, Vetlesen K. Neck/shoulder and low-back disorders in the forestry industry: Relationship to work tasks and perceived psychosocial job stress. Ergonomics. 1998; 41: 1510-1518.

15. Ashby L, Bentley T, Parker R. Musculoskeletal disorders in silviculture and logging 1995-1999. COHFE Rep. 2001; 2, 3: 1-8.

16. Gallis C. Work-related prevalence of musculoskeletal symptoms among Greek forest workers. Int J Ind Ergon. 2006; 36: 731-736.

17. Grzywiński W, Wandycz A, Tomczak A, Jelonek T. The prevalence of self-reported musculoskeletal symptoms among loggers in Poland. Int J Ind Ergon. 2016; 52: 12-17.

18. Steponavičius D, Zinkevičius R. The study of the logging methods prevailed in Lithuania and other countries of Central Europe. EJPAU. 2010; 13, 1: 1-6.

19. Parker R, Sullman M, Kirk P, Ford D. Chainsaw size for delimbing. Ergonomics. 1999; 42: 897-903.

20. Forestry 2015. Central Statistical Office, Warszawa. http://stat.gov. $\mathrm{pl} /$ files/gfx/portalinformacyjny/pl/defaultaktualnosci/5510/1/11/1/ lesnictwo.pdf (access: 2016.05.08).

21. Lehmann G. Praktyczna fizjologia pracy. PZWL, Warszawa, 1966 (in Polish). 
22. Pheasant S. Bodyspace - Anthropometry, Ergonomics and the design of work. 2nd edition. Taylor \& Francis, London, 1996.

23. Vos HW. Physical workload in different body postures, while working near to, or below ground level. Ergonomics. 1973; 16: 817-828.

24. Leszczyński K, Stańczykiewicz A. Workload analysis in logging technology employing a processor aggregated with a farm tractor. Forest Syst. 2015; 24, 2: 1-8.

25. Ottaviani Aalmo G, Magagnotti N, Spinelli R. Forest workers and steep terrain winching: The impact of environmental and anthropometric parameters on performance. Croat J For Eng. 2016; 37: 97-105.

26. Malchaire J, Cock N, Vergracht S. Review of the factors associated with musculoskeletal problems in epidemiological studies. Int Arch Occup Environ Health. 2001; 74: 79-90.

27. Vieira ER, Kumar S. Working postures: A literature review. J Occup Rehabil. 2004; 14: 143-159.
28. Norman R, Wells R. Ergonomic interventions for reducing musculoskeletal disorders: An overview, related issues and future directions. University of Waterloo, Waterloo, 1998.

29. Tirtayasa K, Adiputra IN, Djestawana IG. The change of working posture in manggur decreases cardiovascular load and musculoskeletal complaints among Balinese gamelan craftsmen. J Hum Ergol. 2003; 32: 71-76.

30. Driessen MT, Proper KI, Anema JR, Knol DL, Bongers PM, van der Beek AJ. The effectiveness of participatory ergonomics to prevent lowback and neck pain - results of a cluster randomized controlled trial. Scand J Work Environ Health. 2011; 37: 383-393.

31. Wayan Surata I, Manuaba A, Adiputra N, Sutjana DP. Changing body posture and working system improves workers performance and product quality. Indonesian J Biomed Sci. 2011; 5: 1-14. 